\title{
DOES THE HOUSEHOLD STRUCTURE INFLUENCE REMUNERATION IN POLAND?
}

\author{
Dorota Witkowska \\ University of Lodz, Lodz, Poland \\ e-mail: dorota.witkowska@uni.lodz.pl
}

ORCID: 0000-0001-9538-9589

(C) 2018 Dorota Witkowska

This is an open access article distributed under the Creative Commons Attribution-NonCommercial-NoDerivs license (http://creativecommons.org/licenses/by-nc-nd/3.0/)

DOI: 10.15611/eada.2018.4.02

JEL Classification: C21, E24, J13, J23

\begin{abstract}
The main income determinants are: general economic situation, individual attributes of employees and characteristics of the workplace. However, there are also family duties which affect economic activity and wages, mostly in case of women who are the main care providers to children, the elderly, handicapped or sick. The aim of our research is to find out if the structure of the households influences the monthly remuneration of employees in Poland. The investigation consists in estimation econometric models which describe monthly remuneration on the basis of the microdata. Research is provided for the sample of employees regardless of gender, separately for male and female employees, and for women in three age classes. The analysis based on econometric models enables to find out that on average: (1) male employees earn significantly more than females, (2) married women earn less than unmarried ones while in case of men the situation is the opposite, (3) the motherhood penalty exists in Poland and (4) care providers for the elderly are mostly women, and care duties influence mostly remuneration received by women aged 25-54.
\end{abstract}

Keywords: gender wage disparities, remuneration, structure of the household.

\section{Introduction}

Incomes are determined by many factors such as: (1) the general situation at the labor market, (2) the individual attributes of employees or (3) the characteristics of the particular workplace. A large body of literature points out the problems of gender disparity on the labor market which might cause discrimination. Also, situations when women obtain significantly lower salaries than their male colleagues are quite common. Remuneration disparities are documented and discussed by [Cain 1986, p. 693; McConnell, Brue 1986, p. 290; Blanchard 1997, pp. 302-310; Kot 1999, p. 142; Blau, Kahn 2006; Neuman, Oaxaca 2003; Nopo et al. 2011; Witkowska 2013] among others. Research concerning the situation in Poland was presented by 
[Kot 1999, pp. 225-226; Grajek 2001; Newell, Socha 2005; 2007; Cukrowska 2011; Witkowska 2012; 2014; Kompa, Witkowska 2018].

The research shows that there may be a variety of reasons causing earning disparity. Nopo et al. [2011] distinguish several aspects that have been usually attributed to explain the differences between pay earned by men and women:

- the personal and job characteristics of women, such as: age, education, experience, occupation, working time, job status, type of job contract,

- the labor market structure, for instance occupational segregation by gender, and level of formality,

- institutional, cultural and social norms and traditions.

Historically, gender differences in work values which were perceived as a rationalization for occupational gender segregation, have been de-emphasized in the sociological literature. Gender segregation in the labour market is the tendency for men and women to be employed in different occupations across the entire spectrum of jobs. In other words, occupational segregation is defined as the concentration of males and females in particular kinds of jobs. In the literature horizontal and vertical segregation is identified. The former is the concentration of women in certain sectors of the economy. The latter is the concentration or the over-representation of women in certain levels of the professional hierarchy.

Occupational segregation is derived from the belief that, because of the biological differences between men and women, who are different as far as character and personality are concerned. Men are viewed as being strong and powerful and women as being weak and emotional. More recent experimental studies in behavioral economies have noted essential differences between men and women in individual attitudes towards altruism and greed, leadership and competitiveness [Fortin 2005].

Family duties, especially providing care to children, the elderly, the handicapped and the sick are also important determinants influencing women's economic activity and their wages because the primary caregivers for children, aging spouses and aging parents are mostly women, who are penalized because of that. Since female employees are forced to resign or limit their jobs and if they decide to continue professional activity, they tend to choose caregiver-friendly jobs which usually pay lower wages. According to [Correll et al. 2007], mothers in the workplace face additional disadvantages compared to childless female employees. This causes a pay gap between mothers and women who are not mothers which could be even larger than the gender pay gap. Evidence of the so-called motherhood penalty in Poland is presented in [Cukrowska 2011; Cukrowska-Torzewska 2015; Cukrowska-Torzewska, Lovasz 2016].

The aim of our research is to find out if the structure of the households influences the monthly remuneration of employees in Poland. The investigation consists in estimation econometric models which describe monthly salaries on the basis of the microdata originating from Polish Labor Force Survey (PLFS). The explanatory variables represent employees and workplace controls together with variables 
describing the structure of the households. Analysis is provided for the sample of employees regardless of gender, separately for male and female employees and women in three age classes.

\section{The structure of the sample}

The original PLFS (Q1 2009) database includes information about nearly 55 thousand of respondents. For the purpose of our study, the number of individual records was reduced and contains microdata concerning the respondents who were working during the month preceding the survey only. We also removed all the records with incomplete data ${ }^{1}$. As a result, the sample used in our research contains observations regarding 7044 respondents, among them 3293 women and 3751 men. The female employees are additionally classified into four age groups, however further investigation is provided with the exclusion of the group of women aged 65 and above. The structure of the sample is presented in Tables 1 and 2 .

As one can see (Table 1) 48\% of respondents are heads of the households but among the male employees this percentage is $63 \%$, while for the female employees it is only $31 \%$. Among the women who declared that they are the heads of the household, $81.1 \%$ are $25-54$ years old, $15.5 \%$ aged $55-65,2.4 \%$ are the youngest employees, and $1 \%$ the oldest. If the position in the households for different age groups is considered, we note that the older group of women is considered the higher percentage of heads of households are in the group, since among the oldest female employees $83.3 \%$ are households' heads, in the age group 55-65 these are 58\% of respondents, and $31 \%$ of women aged $25-54$, and only $9 \%$ from the group of the youngest.

Table 1. Structure of the sample in terms of the respondent's position in the household

\begin{tabular}{|l|c|c|c|r|r|r|r|}
\hline \multirow{2}{*}{ Variants of the feature } & \multirow{2}{*}{ Total } & \multirow{2}{*}{ Men } & \multirow{2}{*}{ Women } & \multicolumn{4}{|c|}{ Women aged } \\
\cline { 5 - 8 } & & & & $15-24$ & $25-54$ & $55-65$ & $>65$ \\
\hline Head of the household & 3396 & 2361 & 1035 & 25 & 840 & 160 & 10 \\
\hline Others & 3648 & 1390 & 2258 & 264 & 1876 & 116 & 2 \\
\hline Married & 4795 & 2653 & 2142 & 36 & 1924 & 175 & 7 \\
\hline Others & 2249 & 1098 & 1151 & 253 & 792 & 101 & 5 \\
\hline Sum of respondents & 7044 & 3751 & 3293 & 289 & 2716 & 276 & 12 \\
\hline
\end{tabular}

Source: own elaboration on the basis of [Podliński 2012].

When considering marital status (Table 1), we note that among all the respondents $68 \%$ are married. For the men this percentage is $71 \%$ and for the women, $65 \%$.

${ }^{1}$ In other words, only data concerning respondents who answered all (needed for the model construction) questions in the questionnaire are taken into account. 
Comparing the number of married women in the four distinguished age groups it can be seen that $71 \%$ of women aged $25-54$ are married, $63 \%$ in the group $55-65,55 \%$ in the oldest group, and $12.5 \%$ among the youngest females.

If working-time is taken into account (Table 2), the majority of employees work full time, $73 \%$, and there are no essential differences if different age groups are taken into account, since $62 \%$ of women aged $55-65,74 \%$ women aged $25-54$, and $74.5 \%$ of the youngest female employees, work full time. The only exception appears when the oldest female employees are considered, since the majority of them (two-thirds) work fewer than 40 hours per week. Men are used to work longer than 40 hours per week twice more than women, while women have a part-time job as many as 2.5 times more than men. Among women of different ages, a part-time job is the most popular for the oldest, next for female employees aged 55-65 i.e. 35\%, and for the youngest women $17 \%$, while in the case of women $25-54$ years old, $14 \%$ of them work fewer than 40 hours a week. Female employees from this age group are the most active since $12 \%$ of them work more than 40 hours a week, followed by the groups of the youngest and the oldest women ( $8 \%$ ), while additional work is not popular in the group of female employees 55-65 years old - only $3 \%$.

Table 2. Structure of the sample in terms of working time

\begin{tabular}{|l|r|r|r|r|r|r|c|}
\hline \multirow{2}{*}{$\begin{array}{c}\text { Number of hours worked } \\
\text { during a week }\end{array}$} & Total & \multirow{2}{*}{ Men } & \multirow{2}{*}{ Women } & \multicolumn{4}{|c|}{ Women aged } \\
\cline { 5 - 9 } & & & & $15-24$ & $25-54$ & $55-65$ & $>65$ \\
\hline Less than 20 hours & 343 & 106 & 237 & 22 & 155 & 54 & 6 \\
\hline Between 21 and 39 hours & 431 & 128 & 303 & 28 & 231 & 42 & 2 \\
\hline 40 hours & 5145 & 2748 & 2397 & 216 & 2006 & 172 & 3 \\
\hline More than 40 hours & 1125 & 769 & 356 & 23 & 324 & 8 & 1 \\
\hline
\end{tabular}

Source: own elaboration on the basis of [Podliński 2012].

Table 3 contains information about the households' size and their structure according to the declaration of women from the three age groups. The biggest group of households' members consists of the adults aged 19-65 (75\% for the women from all the three age groups, with a small variance among age groups), followed by the group of employed persons, $40 \%$, which is in the majority a subsample of the former group, and the group with children aged 5-16 (10\% in total but only $7 \%$ in the group of women 55-65 years old). In fact, all children aged 18 and below make up only $20 \%$, and elderly people just $5 \%$ of households' members. This means that over $30 \%$ of households' members aged 19-65 are not employed ${ }^{2}$.

In the households of women aged 15-55, the number of elderly people is about $24 \%$ of the number of children below 19 years old, while in the last age group this

\footnotetext{
${ }^{2}$ The situation in the households, which are described by male respondents, is similar.
} 
Table 3. Number of children and other persons in the households

\begin{tabular}{|l|l|r|r|r|r|}
\hline \multirow{2}{*}{$\begin{array}{c}\text { Set of } \\
\text { variables }\end{array}$} & \multicolumn{1}{|c|}{$\begin{array}{c}\text { Explanatory variable NUM } \\
\text { describing number of: }\end{array}$} & \multicolumn{4}{c|}{ Women aged } \\
\cline { 3 - 6 } & & \multicolumn{1}{c|}{$15-24$} & $25-54$ & $55-65$ & Total \\
\hline S1,3,4 & persons living in the household & 1311 & 10105 & 792 & 12208 \\
\hline S2,3,6 & children below 5 years of age & 37 & 483 & 15 & 535 \\
\hline S2,6 & children aged 6-15 & 133 & 1067 & 59 & 1259 \\
\hline S2,6 & children aged 16-18 & 77 & 587 & 13 & 677 \\
\hline S3 & persons aged 19-65 & 1003 & 7459 & 657 & 9119 \\
\hline S2,4,5,6 & elderly persons over 65 & 61 & 509 & 48 & 618 \\
\hline S4,5 & unemployed children living in the household & 25 & 138 & 14 & 177 \\
\hline S6 & employed children living in the household & 571 & 4098 & 184 & 4853 \\
\hline
\end{tabular}

Source: own elaboration on the basis of [Podliński 2012].

proportion is $55 \%$. In fact, the majority of children and people over 65 live in the households of women aged 25-54 (81.8\%), which makes caregiving an important issue for these respondents and their households.

\section{Model construction}

In our research we use the exponential regression model estimated after linearization (i.e. for the logarithm of wages) by the Ordinary Least Squares method. This type of models is often used in research concerning wages [Grajek 2001; Blau, Kahn 2006; Newell, Reilly 2001; Newell, Socha 2007; Cukrowska 2011]. It is also the usual approach [Newell, Reilly 2001; Grajek 2001; Blau, Kahn 2006; Witkowska 2012; 2013 ] to provide analysis for all respondents and models estimated separately for men and women that simplifies gender wage gap analysis ${ }^{3}$.

In our study, econometric models explaining the natural logarithms of monthly pay, are estimated for the whole sample and separately for subsamples of men and women (denoted by the letters T, M and W, respectively), and for subsamples of women in three age groups, i.e. 15-24, 25-54 and 55-65 (denoted as WA, WB and $\mathrm{WC}$, respectively).

The explanatory variables describe the individual attributes of employees and the structure of their households, together with their workplaces' characteristics, therefore the considered features are both quantitative and qualitative. The last characteristics are represented by ten dummies, which are presented in Table 4 where the symbol of the feature together with its description, information about number of variables (dummies) representing different variants for each feature (in parenthesis) and the reference variant are given. Quantitative variables are defined as age (AGE) and age

\footnotetext{
${ }^{3}$ Such an approach, often used in gender disparities analysis, was proposed by [Juhn et. al 1991].
} 
Table 4. List of dummies

\begin{tabular}{|l|l|l|}
\hline \multicolumn{2}{|c|}{ Symbol and description of features (number of dummies) } & \multicolumn{1}{|c|}{ Reference variant } \\
\hline GEN & Gender (2) & women \\
\hline REL & Relationship with the head of the household (2) & not a household head \\
\hline MAR & Marital status (2) & not married \\
\hline RES & Size of the place of residence measured by number of inhabitants (6) & countryside \\
\hline EDU & Level of education (6) & $\begin{array}{l}\text { lower than } \\
\text { preliminary }\end{array}$ \\
\hline SIZ & Size class of the workplace measured by number of employees (6) & 20-49 employees \\
\hline OWN & Ownership of the enterprise or institution (2) & private \\
\hline WOR & Working profile measured by work-time (4) & 40 hours per week \\
\hline SEC & Economic sector of employment (4) & other \\
\hline OCU & Occupation class (9) & industry workers \\
\hline
\end{tabular}

Source: own elaboration.

squared, together with eight variables related to the family situation (NUM) which are described in Table 3. It is worth mentioning that all variables describing structure of the household cannot be included in one model at the same time since some information is repeated by more than one variable. Therefore, we can distinguish six sets of "family variables" (denoted as: S1, S2, .., S6) which determine the model specification. The set of variables contains from one (S1) to five (S6) variables which is visible in Table 3, where the first column contains information about the belongingness of each variable to the determined set of explanatory variables.

\section{Empirical results}

As was already mentioned, all the models are denoted according to their specification (i.e. variable sets S1-S6) and the sample which is used in the estimation procedure (e.g. men or women). For instance, MT2 denotes the model built for the second set of "family" variables S2 and estimated for the whole sample. While model MWB2 contains the same set of "family" variables, it is estimated for the subsample of women aged 25-54. Tables 5 to 9 contain estimation results obtained for 24 models applying the OLS method. In the tables the parameter estimates and determination coefficients are presented. Symbol: *denotes significance level $\alpha=0.1$, **for $\alpha=0.05$, and $* * *$ for $\alpha=0.01 ; \times-$ denotes lack of variables. In our study we assume that a variable is statistically significant if the null hypothesis can be rejected at significance level $\alpha=0.05$ or less.

In Tables 5 and 6 the models constructed for the second and the sixth sets of variables but estimated using different samples, are presented. One may note that in both models estimated for the whole sample, the men earn significantly more than the 
women since the variable man is significant with positive impact onto remuneration. It is also visible that the models estimated for the whole sample and subsample of the women are characterized by high determination coefficients, while for the men the fitting of the models is low 4 .

There are several variables which show influence in the same direction in all the models presented in Tables 5 and 6 :

- a significant and positive impact is observed for: age, household head, living in the city with more than 100 thousand inhabitants, university education and higher, vocational or general secondary education, working time longer than 40 hours per week, all economic sectors, and some occupations such as: managerial, professional, technical and skilled workers together with a workplace with more than 100 employees (except for models MW4 and MW5 where the variable describing workplace with 101-250 employees is insignificant);

- a significant and negative impact is observed for: age squared, working time shorter than 40 hours per week, and number of children 16-18 years old in the household.

In other words, the models prove that remuneration increases with age but only to a certain limit, and after obtaining the specified age the pay starts to decrease. One should also note that in the case of dummies, the parameter estimates inform about the relative influence of the certain variant of the feature (represented by the dummy) in comparison to the reference variant. For example, the positive influence of the variable household head means that heads of the households earn more than other family members. Employees living in big cities ear more than those living in the country. Also, employees with a higher education earn more when compared with the ones with primary or lower education. A part-time job generates lower monthly salary than a full-time job, and an increase in the number of children aged 16-18 years in a household causes a decrease of remuneration.

Other variants of variables are either insignificant or their impact depends on the estimation sample. Insignificant variables are: the number of elderly persons or children 6-15 years old in the household, public ownership of the place of work and living in a city of 50-100 thousand inhabitants, although the latter variable is significant with a positive influence in the models: MT1, MT3, MT4 and MT5.

There are interesting results concerning situations when the same variable has the opposite impact for men and for women, and here are some such cases:

- Married women earn less than unmarried ones while married men earn more than unmarried ones.

- Women working in sales and services and being unskilled workers earn more than female industrial workers, while for male employees the situation is the reverse.

\footnotetext{
${ }^{4}$ In fact similar results are obtained for all 18 models (which are not presented in this paper) i.e. models specified according to six data sets S1-S6 and estimated for the whole sample and subsamples of men and women.
} 
Does the household structure influence remuneration in Poland?

Table 5. Parameter estimates of models with the set of variables S2

\begin{tabular}{|c|c|c|c|c|c|c|c|}
\hline \multirow{2}{*}{ Feature } & \multirow{2}{*}{$\begin{array}{c}\text { Model } \\
\text { Variable }\end{array}$} & \multicolumn{2}{|c|}{ MT2 } & \multicolumn{2}{|l|}{ MM2 } & \multicolumn{2}{|c|}{ MW2 } \\
\hline & & \multicolumn{6}{|c|}{ Parameter estimates } \\
\hline \multirow{2}{*}{ AGE } & age & 0.1003 & $* * *$ & 0.0299 & $* * *$ & 0.1464 & $* * *$ \\
\hline & $a g e^{2}$ & -0.0012 & $* * *$ & -0.0004 & $* * *$ & -0.0017 & $* * *$ \\
\hline GEN & man & 0.2509 & $* * *$ & & & & \\
\hline REL & household head & 0.0598 & $* * *$ & 0.0873 & $* * *$ & 0.0587 & $* * *$ \\
\hline MAR & married & 0.0026 & & 0.1015 & $* * *$ & -0.0451 & $* * *$ \\
\hline \multirow{5}{*}{ RES } & $>100$ thousand & 0.0948 & $* * *$ & 0.0756 & $* * *$ & 0.1111 & $* * *$ \\
\hline & 50-100 thousand & 0.0320 & $*$ & 0.0334 & & 0.0285 & \\
\hline & 10-50 thousand & 0.0135 & & -0.0199 & & 0.0431 & $* *$ \\
\hline & 5-10 thousand & -0.0714 & $* * *$ & -0.0819 & $* * *$ & -0.0648 & $*$ \\
\hline & 2-5 thousand & 0.0088 & & -0.0543 & & 0.0960 & $* *$ \\
\hline \multirow{5}{*}{ EDU } & university (at least Ph.D.) & 0.6068 & $* * *$ & 0.5780 & $* * *$ & 0.6659 & $* * *$ \\
\hline & university & 0.3206 & $* * *$ & 0.2174 & $* * *$ & 0.4001 & $* * *$ \\
\hline & post-secondary & 0.1151 & $* * *$ & 0.0783 & $*$ & 0.1529 & $* * *$ \\
\hline & vocational or general secondary & 0.1443 & $* * *$ & 0.0891 & $* * *$ & 0.1880 & $* * *$ \\
\hline & primary or lower vocational & -0.0643 & $* * *$ & -0.1120 & $* * *$ & -0.0114 & \\
\hline \multirow{5}{*}{ SIZ } & $\leq 10$ employees & -0.0381 & $* *$ & -0.0971 & $* * *$ & -0.0203 & \\
\hline & 11-19 employees & -0.0111 & & -0.0758 & $* * *$ & 0.0405 & $*$ \\
\hline & 50-100 employees & 0.0359 & $* *$ & 0.0221 & & 0.0507 & $* *$ \\
\hline & 101-250 employees & 0.0566 & $* * *$ & 0.0623 & $* * *$ & 0.0483 & $* *$ \\
\hline & $>250$ employees & 0.1217 & $* * *$ & 0.1175 & $* * *$ & 0.1119 & $* * *$ \\
\hline OWN & public & 0.0059 & & 0.0214 & & -0.0147 & \\
\hline \multirow{3}{*}{ WOR } & less than 20 hours per week & -0.5779 & $* * *$ & -0.7730 & $* * *$ & -0.5177 & $* * *$ \\
\hline & from 21 to 40 hours per week & -0.1979 & $* * *$ & -0.3601 & $* * *$ & -0.1405 & $* * *$ \\
\hline & more than 40 hours per week & 0.1046 & $* * *$ & 0.1260 & $* * *$ & 0.0605 & $* * *$ \\
\hline \multirow{3}{*}{ SEC } & agriculture & 4.7773 & $* * *$ & 6.5484 & $* * *$ & 3.5833 & $* * *$ \\
\hline & industry & 4.8585 & $* * *$ & 6.5697 & $* * *$ & 3.7418 & $* * *$ \\
\hline & service & 4.7983 & $* * *$ & 6.5365 & $* * *$ & 3.6171 & $* * *$ \\
\hline \multirow{8}{*}{ OCU } & managerial & 0.4267 & $* * *$ & 0.3696 & $* * *$ & 0.6488 & $* * *$ \\
\hline & professional & 0.3123 & $* * *$ & 0.2786 & $* * *$ & 0.5015 & $* * *$ \\
\hline & technical & 0.1891 & $* * *$ & 0.1582 & $* * *$ & 0.3932 & $* * *$ \\
\hline & clerical & 0.0783 & $* * *$ & -0.0457 & $*$ & 0.3297 & $* * *$ \\
\hline & sales \& services & 0.0329 & & -0.0857 & $* * *$ & 0.2854 & $* * *$ \\
\hline & farmers, fishermen, etc. & 0.0804 & & -0.0780 & & 0.6890 & $* * *$ \\
\hline & skilled workers & 0.0749 & $* * *$ & 0.0376 & $* *$ & 0.2241 & $* * *$ \\
\hline & unskilled workers & -0.0913 & $* * *$ & -0.1509 & $* * *$ & 0.1184 & $* * *$ \\
\hline \multirow{4}{*}{ NUM } & children $\leq 5$ years old & 0.0206 & $*$ & 0.0029 & & 0.0134 & \\
\hline & children 6-15 years old & 0.0015 & & -0.0076 & & 0.0060 & \\
\hline & children 16-18 years old & -0.0513 & $* * *$ & -0.0294 & $* *$ & -0.0720 & $* * *$ \\
\hline & elderly persons $>65$ years old & 0.0067 & & -0.0027 & & 0.0263 & $*$ \\
\hline \multicolumn{2}{|l|}{$\mathrm{R}^{2}$ adjusted } & \multicolumn{2}{|l|}{0.997} & \multicolumn{2}{|l|}{0.445} & \multicolumn{2}{|c|}{0.997} \\
\hline
\end{tabular}

Source: own elaboration. 
Table 6. Parameter estimates of models with the set of variables S6

\begin{tabular}{|c|c|c|c|c|c|c|c|}
\hline & Model & \multicolumn{2}{|c|}{ MT6 } & \multicolumn{2}{|c|}{ MM6 } & \multicolumn{2}{|c|}{ MW6 } \\
\hline Feature & Variable & & & & & & \\
\hline \multirow[t]{2}{*}{ AGE } & age & 0.1003 & $* * *$ & 0.0297 & $* * *$ & 0.1463 & $* * *$ \\
\hline & $a g e^{2}$ & -0.0012 & $* * *$ & -0.0004 & $* * *$ & -0.0017 & $* * *$ \\
\hline GEN & man & 0.2510 & $* * *$ & & & & \\
\hline REL & household head & 0.0595 & $* * *$ & 0.0852 & $* * *$ & 0.0590 & $* * *$ \\
\hline MAR & married & 0.0023 & & 0.1006 & $* * *$ & -0.0444 & $* * *$ \\
\hline \multirow[t]{5}{*}{ RES } & $>100$ thousand & 0.0945 & $* * *$ & 0.0730 & $* * *$ & 0.1118 & $* * *$ \\
\hline & 50-100 thousand & 0.0317 & $*$ & 0.0325 & & 0.0293 & \\
\hline & 10-50 thousand & 0.0133 & & -0.0219 & & 0.0435 & $* *$ \\
\hline & 5-10 thousand & -0.0715 & $* * *$ & -0.0840 & $* * *$ & -0.0652 & $*$ \\
\hline & 2-5 thousand & 0.0087 & & -0.0559 & $*$ & 0.0955 & $* *$ \\
\hline \multirow[t]{5}{*}{ EDU } & university (at least Ph.D.) & 0.6062 & $* * *$ & 0.5738 & $* * *$ & 0.6673 & $* * *$ \\
\hline & university & 0.3201 & $* * *$ & 0.2145 & $* * *$ & 0.4011 & $* * *$ \\
\hline & post-secondary & 0.1147 & $* * *$ & 0.0767 & * & 0.1539 & $* * *$ \\
\hline & vocational or general secondary & 0.1442 & **** & 0.0881 & $* * *$ & 0.1881 & $* * *$ \\
\hline & primary or lower vocational & -0.0639 & $* * *$ & -0.1091 & $* * *$ & -0.0117 & \\
\hline \multirow[t]{5}{*}{ SIZ } & $\leq 10$ employees & -0.0383 & $* *$ & -0.0994 & $* * *$ & -0.0206 & \\
\hline & 11-19 employees & -0.0113 & & -0.0771 & $* * *$ & 0.0406 & $*$ \\
\hline & 50-100 employees & 0.0357 & $* *$ & 0.0196 & & 0.0505 & $* *$ \\
\hline & 101-250 employees & 0.0564 & $* * *$ & 0.0607 & $* * *$ & 0.0481 & $* *$ \\
\hline & $>250$ employees & 0.1215 & $* * *$ & 0.1155 & $* * *$ & 0.1118 & $* * *$ \\
\hline OWN & public & 0.0059 & & 0.0212 & & -0.0151 & \\
\hline \multirow[t]{3}{*}{ WOR } & less than 20 hours per week & -0.5780 & $* * *$ & -0.7739 & $* * *$ & -0.5175 & $* * *$ \\
\hline & from 21 to 40 hours per week & -0.1980 & $* * *$ & -0.3616 & $* * *$ & -0.1405 & $* * *$ \\
\hline & more than 40 hours per week & 0.1045 & $* * *$ & 0.1250 & $* * *$ & 0.0607 & $* * *$ \\
\hline \multirow[t]{3}{*}{ SEC } & agriculture & 4.7777 & $* * *$ & 6.5584 & $* * *$ & 3.5833 & $* * *$ \\
\hline & industry & 4.8591 & *** & 6.5803 & $* * *$ & 3.7417 & $* * *$ \\
\hline & service & 4.7989 & $* * *$ & 6.5477 & $* * *$ & 3.6174 & $* * *$ \\
\hline \multirow[t]{8}{*}{$\mathrm{OCU}$} & managerial & 0.4268 & $* * *$ & 0.3703 & $* * *$ & 0.6487 & $* * *$ \\
\hline & professional & 0.3124 & $* * *$ & 0.2800 & $* * *$ & 0.5013 & $* * *$ \\
\hline & technical & 0.1891 & $* * *$ & 0.1586 & $* * *$ & 0.3932 & $* * *$ \\
\hline & \begin{tabular}{|l|} 
clerical \\
\end{tabular} & 0.0784 & $* * *$ & -0.0452 & & 0.3294 & $* * *$ \\
\hline & sales \& services & 0.0327 & & -0.0864 & $* * *$ & 0.2857 & $* * *$ \\
\hline & farmers. fishermen etc. & 0.0808 & & -0.0745 & & 0.6901 & $* * *$ \\
\hline & skilled workers & 0.0746 & $* * *$ & 0.0363 & $* *$ & 0.2245 & $* * *$ \\
\hline & unskilled workers & -0.0913 & $* * *$ & -0.1514 & $* * *$ & 0.1178 & $* * *$ \\
\hline \multirow[t]{5}{*}{ NUM } & children $\leq 5$ years old & 0.0207 & $* *$ & 0.0035 & & 0.0132 & \\
\hline & children 6-15 years old & 0.0015 & & -0.0073 & & 0.0058 & \\
\hline & children 16-18 years old & -0.0513 & **** & -0.0289 & $* *$ & -0.0717 & $* * *$ \\
\hline & elderly persons $>65$ years old & 0.0067 & & -0.0035 & & 0.0264 & $*$ \\
\hline & employed persons & -0.0095 & & -0.0567 & $* *$ & 0.0204 & \\
\hline \multicolumn{2}{|l|}{$\mathrm{R}^{2}$ adjusted } & \multicolumn{2}{|c|}{0.997} & \multicolumn{2}{|c|}{0.446} & \multicolumn{2}{|c|}{0.997} \\
\hline
\end{tabular}

Source: own elaboration. 
There are also some situations when the distinguished factor is significant for one gender and insignificant for the other. For instance, women working as clerical staff, farmers, etc. obtain higher remuneration than industry workers, while for men these variants of variables are statistically insignificant. A similar situation occurs for respondents living in towns with 2-5 and 10-50 thousand inhabitants, employees with a post-secondary education and working in enterprises or institutions employing 50-100 employees. A different situation is observed for respondents living in towns with 5-10 thousand inhabitants since men earn significantly more than those living in the country, while for women this variable is insignificant. A significantly negative impact is also observed for male employees with a primary or lower vocational education, working in institutions with not more than 20 employees, and for the number of employed persons in the household. These variables do not influence women's wages.

The impact of explanatory variables to monthly remuneration varies in the models estimated for female employees of different age, only with working time shorter than 40 hours per week, age and age squared keep the same impact in all the 18 models estimated for women of different age. The most similar relations to the one observed for all respondents and subsamples of men and women, are visible for the subsample of women aged 25-54. For instance, in models MWB1-MWB6 the earnings of employees working for enterprises with 101-250 employees, are not significantly larger than those obtained in a workplace with 20-49 employees (which is the same result as for models MW4 and MW5).

Considering the remaining variables, we note that in majority of cases the following factors are insignificant in all the models estimated for the youngest and the oldest age class: workplace with more than 100 employees, working time longer than 40 hours per week, and occupation as a skilled or technical worker. Additionally, for the oldest group of women, being a household head, living in a city with more than 100 thousand inhabitants and working as a professional do seem to be significant factors.

Analyzing models estimated for the youngest group of women, one may note that university education and higher, together with vocational or general secondary education and managerial position, is insignificant whereas working in industry and services significantly negatively influences earnings in all the six models. Also, being a household head is insignificant in MWA3, as is the number of children 16-18 years old in MWA2.

Married women earn more than the unmarried ones when aged 15-24 (MWA4) or 55-64 (MWC3), and they earn less than unmarried ones when aged 25-54 (MWA4). According to models MWA1-MWA5, the youngest women working in the public sector earn significantly less than those working in private sector. In the rest of the models this feature is insignificant.

Considering the variables dedicated to the structure of the households, we note that these variables are insignificant in the models estimated for the oldest group of 
Table 7. Parameter estimates of models estimated for women aged 15-24

\begin{tabular}{|c|c|c|c|c|c|c|c|}
\hline \multirow{3}{*}{$\begin{array}{c}\text { Feature } \\
1 \\
\end{array}$} & \multirow{2}{*}{$\begin{array}{c}\text { Model } \\
\text { Variable }\end{array}$} & \multicolumn{2}{|c|}{ MWA1 } & \multicolumn{2}{|c|}{ MWA2 } & \multicolumn{2}{|c|}{ MWA3 } \\
\hline & & \multicolumn{6}{|c|}{ Parameter estimates } \\
\hline & 2 & \multicolumn{2}{|l|}{3} & \multicolumn{2}{|l|}{4} & \multicolumn{2}{|l|}{5} \\
\hline \multirow{2}{*}{ AGE } & age & 1.2593 & $* * *$ & 1.1765 & $* * *$ & 1.2586 & *** \\
\hline & $a g e^{2}$ & -0.0267 & $* * *$ & -0.0249 & $* * *$ & -0.0267 & *** \\
\hline REL & household head & 0.1737 & $* *$ & 0.1833 & $* *$ & 0.1614 & * \\
\hline MAR & married & 0.1208 & * & 0.1110 & $*$ & 0.1108 & \\
\hline \multirow{5}{*}{ RES } & $>100$ thousand & 0.1255 & $* *$ & 0.1364 & $* *$ & 0.1263 & $* *$ \\
\hline & 50-100 thousand & -0.0163 & & -0.0294 & & -0.0181 & \\
\hline & 10-50 thousand & 0.0092 & & 0.0188 & & 0.0126 & \\
\hline & 5-10 thousand & -0.2499 & $* *$ & -0.2390 & $* *$ & -0.2419 & $* *$ \\
\hline & 2-5 thousand & -0.0318 & & -0.0105 & & -0.0293 & \\
\hline \multirow{4}{*}{ EDU } & university & 0.0424 & & 0.0554 & & 0.0505 & \\
\hline & post-secondary & -0.0672 & & -0.0413 & & -0.0666 & \\
\hline & vocational or general secondary & 0.0414 & & 0.0514 & & 0.0449 & \\
\hline & primary or lower vocational & -0.3264 & $* *$ & -0.3027 & $* *$ & -0.3397 & *** \\
\hline \multirow{5}{*}{ SIZ } & $\leq 10$ employees & -0.1106 & & -0.1256 & * & -0.1106 & \\
\hline & 11-19 employees & -0.0659 & & -0.0766 & & -0.0685 & \\
\hline & 50-100 employees & 0.0738 & & 0.0621 & & 0.0733 & \\
\hline & 101-250 employees & 0.0113 & & -0.0009 & & 0.0157 & \\
\hline & $>250$ employees & -0.0424 & & -0.0576 & & -0.0392 & \\
\hline OWN & public & -0.1231 & $* *$ & -0.1241 & $* *$ & -0.1253 & ** \\
\hline \multirow{3}{*}{ WOR } & less than 20 hours per week & -0.8639 & *** & -0.8695 & $* * *$ & -0.8599 & $* * *$ \\
\hline & from 21 to 40 hours per week & -0.3012 & $* * *$ & -0.2817 & $* * *$ & -0.3025 & $* * *$ \\
\hline & more than 40 hours per week & 0.0471 & & 0.0542 & & 0.0454 & \\
\hline \multirow{2}{*}{ SEC } & industry & -7.7395 & $* *$ & -6.7954 & * & -7.7174 & *** \\
\hline & service & -7.7188 & $* *$ & -6.7786 & $*$ & -7.6888 & $* *$ \\
\hline \multirow{7}{*}{$\mathrm{OCU}$} & managerial & 0.1930 & & 0.1707 & & 0.1846 & \\
\hline & professional & 0.2940 & $* *$ & 0.2909 & $* *$ & 0.2841 & $*$ \\
\hline & technical & -0.0312 & & -0.0309 & & -0.0442 & \\
\hline & clerical & -0.0715 & & -0.0698 & & -0.0832 & \\
\hline & sales \& services & -0.0947 & & -0.0929 & & -0.1037 & \\
\hline & skilled workers & -0.1515 & & -0.1695 & & -0.1492 & \\
\hline & unskilled workers & -0.0846 & & -0.0998 & & -0.1011 & \\
\hline \multirow{6}{*}{ NUM } & persons in the household & -0.0054 & & & & 0.0002 & \\
\hline & children $\leq 5$ years old & & & 0.0242 & & 0.0277 & \\
\hline & children 6-15 years old & & & 0.0019 & & & \\
\hline & children 16-18 years old & & & -0.0773 & $*$ & & \\
\hline & persons $19-65$ years old & & & & & -0.0129 & \\
\hline & elderly persons $>65$ years old & & & 0.0499 & & & \\
\hline \multicolumn{2}{|l|}{$\mathrm{R}^{2}$ adjusted } & \multicolumn{2}{|c|}{0.473} & 0.49 & & \multicolumn{2}{|c|}{0.476} \\
\hline
\end{tabular}


Does the household structure influence remuneration in Poland?

\begin{tabular}{|c|c|c|c|c|c|c|c|}
\hline 1 & 2 & \multicolumn{2}{|l|}{3} & \multicolumn{2}{|l|}{4} & \multicolumn{2}{|l|}{5} \\
\hline \multirow{2}{*}{ AGE } & age & 1.3318 & $* * *$ & 1.3065 & $* * *$ & 1.1419 & $* * *$ \\
\hline & $a g e^{2}$ & -0.0284 & $* * *$ & -0.0278 & $* * *$ & -0.0242 & $* * *$ \\
\hline REL & household head & 0.1815 & $* *$ & 0.1841 & $* *$ & 0.1737 & $* *$ \\
\hline MAR & married & 0.1347 & $* *$ & 0.1209 & * & 0.1091 & $*$ \\
\hline \multirow{5}{*}{ RES } & $>100$ thousand & 0.1294 & $* *$ & 0.1426 & $* *$ & 0.1288 & $* *$ \\
\hline & 50-100 thousand & -0.0214 & & -0.0130 & & -0.0316 & \\
\hline & 10-50 thousand & 0.0186 & & 0.0228 & & 0.0226 & \\
\hline & 5-10 thousand & -0.2394 & $* *$ & -0.2410 & $* *$ & -0.2263 & $* *$ \\
\hline & 2-5 thousand & -0.0161 & & -0.0162 & & -0.0013 & \\
\hline \multirow{4}{*}{ EDU } & university & 0.0530 & & 0.0659 & & 0.0452 & \\
\hline & post-secondary & -0.0403 & & -0.0419 & & -0.0216 & \\
\hline & vocational or general secondary & 0.0489 & & 0.0556 & & 0.0560 & \\
\hline & primary or lower vocational & -0.3101 & $* *$ & -0.3048 & $* *$ & -0.3083 & $* *$ \\
\hline \multirow{5}{*}{ SIZ } & $\leq 10$ employees & -0.1112 & & -0.1184 & * & -0.1115 & \\
\hline & 11-19 employees & -0.0641 & & -0.0659 & & -0.0702 & \\
\hline & 50-100 employees & 0.0762 & & 0.0689 & & 0.0630 & \\
\hline & 101-250 employees & 0.0187 & & 0.0041 & & 0.0123 & \\
\hline & $>250$ employees & -0.0438 & & -0.0514 & & -0.0456 & \\
\hline OWN & public & -0.1332 & $* *$ & -0.1270 & $* *$ & -0.1006 & \\
\hline \multirow{3}{*}{ WOR } & less than 20 hours per week & -0.8587 & $* * *$ & -0.8627 & $* * *$ & -0.8718 & $* * *$ \\
\hline & from 21 to 40 hours per week & -0.2906 & $* * *$ & -0.2947 & $* * *$ & -0.2841 & $* * *$ \\
\hline & more than 40 hours per week & 0.0640 & & 0.0625 & & 0.0502 & \\
\hline \multirow{2}{*}{ SEC } & industry & -8.4822 & $* *$ & -8.2799 & $* *$ & -6.3605 & $*$ \\
\hline & service & -8.4607 & $* *$ & -8.2625 & $* *$ & -6.3519 & $*$ \\
\hline \multirow{7}{*}{$\mathrm{OCU}$} & managerial & 0.1619 & & 0.1568 & & 0.1545 & \\
\hline & professional & 0.2835 & $*$ & 0.2914 & $* *$ & 0.2583 & $*$ \\
\hline & technical & -0.0391 & & -0.0350 & & -0.0489 & \\
\hline & clerical & -0.0791 & & -0.0730 & & -0.0947 & \\
\hline & sales \& services & -0.1030 & & -0.0921 & & -0.1271 & \\
\hline & skilled workers & -0.1655 & & -0.1550 & & -0.2072 & $*$ \\
\hline & unskilled workers & -0.0853 & & -0.0850 & & -0.1444 & \\
\hline \multirow{8}{*}{ NUM } & persons in the household & -0.0269 & & & & & \\
\hline & children $\leq 5$ years old & & & & & 0.0303 & \\
\hline & children 6-15 years old & & & & & 0.0046 & \\
\hline & children 16-18 years old & & & & & -0.0877 & $* *$ \\
\hline & persons $19-65$ years old & & & & & & \\
\hline & elderly persons $>65$ years old & 0.0824 & $*$ & 0.0573 & & 0.0540 & \\
\hline & unemployed children & 0.0203 & & -0.0064 & & & \\
\hline & employed persons & & & & & -0.1544 & $* *$ \\
\hline \multicolumn{2}{|c|}{$\mathrm{R}^{2}$ adjusted } & \multicolumn{2}{|c|}{0.482} & \multicolumn{2}{|c|}{0.479} & \multicolumn{2}{|c|}{0.506} \\
\hline
\end{tabular}

Source: own elaboration. 
Table 8. Parameter estimates of models estimated for women aged 25-54

\begin{tabular}{|c|c|c|c|c|c|c|c|}
\hline \multirow{3}{*}{$\begin{array}{c}\text { Feature } \\
1 \\
\end{array}$} & \multirow{2}{*}{$\begin{array}{c}\text { Model } \\
\text { Variable }\end{array}$} & \multicolumn{2}{|c|}{ MWB1 } & \multicolumn{2}{|c|}{ MWB2 } & \multicolumn{2}{|c|}{ MWB3 } \\
\hline & & \multicolumn{6}{|c|}{ Parameter estimates } \\
\hline & 2 & \multicolumn{2}{|l|}{3} & \multicolumn{2}{|l|}{4} & \multicolumn{2}{|l|}{5} \\
\hline \multirow{2}{*}{ AGE } & age & 0.2251 & $* * *$ & 0.2318 & $* * *$ & 0.2396 & $* * *$ \\
\hline & age & -0.0027 & $* * *$ & -0.0028 & $* * *$ & -0.0029 & $* * *$ \\
\hline REL & household head & 0.0488 & $* * *$ & 0.0463 & $* * *$ & 0.0683 & $* * *$ \\
\hline MAR & married & -0.0249 & & -0.0242 & & -0.0156 & \\
\hline \multirow{5}{*}{ RES } & $>100$ thousand & 0.1115 & $* * *$ & 0.1008 & $* * *$ & 0.1089 & *** \\
\hline & 50-100 thousand & 0.0290 & & 0.0164 & & 0.0232 & \\
\hline & 10-50 thousand & 0.0497 & $* * *$ & 0.0372 & ** & 0.0464 & $* *$ \\
\hline & 5-10 thousand & -0.0371 & & -0.0461 & & -0.0401 & \\
\hline & $2-5$ thousand & 0.0888 & $* *$ & 0.0813 & ** & 0.0880 & *** \\
\hline \multirow{5}{*}{ EDU } & university (at least Ph.D.) & 0.3163 & $* * *$ & 0.2927 & ** & 0.3141 & *** \\
\hline & university & 0.3893 & $* * *$ & 0.3809 & $* * *$ & 0.3534 & $* * *$ \\
\hline & post-secondary & 0.1441 & $* * *$ & 0.1432 & $* * *$ & 0.1238 & *** \\
\hline & vocational or general secondary & 0.1157 & $* * *$ & 0.1170 & $* * *$ & 0.1045 & $* * *$ \\
\hline & primary or lower vocational & 0.0272 & & 0.0317 & & 0.0347 & \\
\hline \multirow{5}{*}{ SIZ } & $\leq 10$ employees & -0.0320 & & -0.0350 & & -0.0425 & $*$ \\
\hline & 11-19 employees & 0.0136 & & 0.0143 & & 0.0127 & \\
\hline & 50-100 employees & 0.0340 & & 0.0314 & & 0.0276 & \\
\hline & 101-250 employees & 0.0373 & & 0.0356 & & 0.0366 & \\
\hline & $>250$ employees & 0.0987 & $* * *$ & 0.0945 & $* * *$ & 0.0982 & *** \\
\hline OWN & public & -0.0188 & & -0.0159 & & -0.0134 & \\
\hline \multirow{3}{*}{ WOR } & less than 20 hours per week & -0.4311 & $* * *$ & -0.4358 & *** & -0.4236 & $* * *$ \\
\hline & from 21 to 40 hours per week & -0.1713 & $* * *$ & -0.1655 & $* * *$ & -0.1622 & **** \\
\hline & more than 40 hours per week & 0.0553 & $* * *$ & 0.0592 & *** & 0.0624 & $* * *$ \\
\hline \multirow{3}{*}{ SEC } & agriculture & 2.2099 & **** & 2.1095 & **** & 1.9218 & *** \\
\hline & industry & 2.2730 & $* * *$ & 2.1766 & $* * *$ & 1.9897 & $* * *$ \\
\hline & service & 2.1840 & $* * *$ & 2.0859 & *** & 1.9061 & $* * *$ \\
\hline \multirow{8}{*}{$\mathrm{OCU}$} & managerial & 0.5601 & $* * *$ & 0.5569 & $* * *$ & 0.5563 & $* * *$ \\
\hline & professional & 0.4427 & $* * *$ & 0.4404 & $* * *$ & 0.4506 & $* * *$ \\
\hline & technical & 0.3629 & $* * *$ & 0.3588 & *** & 0.3608 & **** \\
\hline & clerical & 0.3004 & $* * *$ & 0.2946 & $* * *$ & 0.2903 & $* * *$ \\
\hline & \begin{tabular}{|l} 
sales \& services \\
\end{tabular} & 0.2041 & $* * *$ & 0.1993 & *** & 0.1968 & $* * *$ \\
\hline & farmers. fishermen etc. & 0.5744 & $* * *$ & 0.6021 & *** & 0.5609 & $* * *$ \\
\hline & \begin{tabular}{|l} 
skilled workers \\
\end{tabular} & 0.1579 & $* * *$ & 0.1578 & *** & 0.1592 & $* * *$ \\
\hline & unskilled workers & 0.0479 & & 0.0405 & & 0.0308 & \\
\hline \multirow{6}{*}{ NUM } & persons in the household & -0.0002 & & & & -0.0516 & $* * *$ \\
\hline & children $\leq 5$ years old & & & 0.0082 & & 0.0510 & *** \\
\hline & children 6-15 years old & & & -0.0001 & & & \\
\hline & children 16-18 years old & & & -0.0892 & $* * *$ & & \\
\hline & persons $19-65$ years old & & & & & 0.0865 & *** \\
\hline & elderly persons $>65$ years old & & & -0.0298 & *** & & \\
\hline \multicolumn{2}{|l|}{$\mathrm{R}^{2}$ adjusted } & \multicolumn{2}{|c|}{0.979} & \multicolumn{2}{|c|}{0.979} & \multicolumn{2}{|c|}{0.979} \\
\hline
\end{tabular}




\begin{tabular}{|c|c|c|c|c|c|c|c|}
\hline 1 & 2 & \multicolumn{2}{|l|}{3} & \multicolumn{2}{|l|}{4} & \multicolumn{2}{|l|}{5} \\
\hline \multirow{2}{*}{ AGE } & age & 0.2290 & $* * *$ & 0.2293 & $* * *$ & 0.2318 & $* * *$ \\
\hline & $a g e^{2}$ & -0.0027 & $* * *$ & -0.0027 & $* * *$ & -0.0028 & $* * *$ \\
\hline REL & household head & 0.0510 & $* * *$ & 0.0424 & $* * *$ & 0.0465 & $* * *$ \\
\hline MAR & married & -0.0402 & $* *$ & -0.0247 & & -0.0237 & \\
\hline \multirow{5}{*}{ RES } & $>100$ thousand & 0.1090 & $* * *$ & 0.0986 & $* * *$ & 0.1016 & $* * *$ \\
\hline & 50-100 thousand & 0.0310 & & 0.0193 & & 0.0172 & \\
\hline & 10-50 thousand & 0.0462 & $* *$ & 0.0379 & $* *$ & 0.0376 & $* *$ \\
\hline & 5-10 thousand & -0.0366 & & -0.0427 & & -0.0461 & \\
\hline & 2-5 thousand & 0.0889 & $* *$ & 0.0828 & $* *$ & 0.0807 & $* *$ \\
\hline \multirow{5}{*}{ EDU } & university (at least Ph.D.) & 0.3086 & $* * *$ & 0.3127 & $* * *$ & 0.2937 & $* *$ \\
\hline & university & 0.3857 & $* * *$ & 0.3866 & $* * *$ & 0.3815 & $* * *$ \\
\hline & post-secondary & 0.1411 & $* * *$ & 0.1441 & $* * *$ & 0.1440 & $* * *$ \\
\hline & vocational or general secondary & 0.1171 & $* * *$ & 0.1170 & $* * *$ & 0.1173 & $* * *$ \\
\hline & primary or lower vocational & 0.0274 & & 0.0276 & & 0.0316 & \\
\hline \multirow{5}{*}{ SIZ } & $\leq 10$ employees & -0.0398 & $*$ & -0.0347 & & -0.0350 & \\
\hline & 11-19 employees & 0.0137 & & 0.0144 & & 0.0144 & \\
\hline & 50-100 employees & 0.0333 & & 0.0338 & & 0.0311 & \\
\hline & 101-250 employees & 0.0358 & & 0.0367 & & 0.0354 & \\
\hline & $>250$ employees & 0.0963 & $* * *$ & 0.0978 & $* * *$ & 0.0946 & $* * *$ \\
\hline OWN & public & -0.0188 & & -0.0184 & & -0.0160 & \\
\hline \multirow{3}{*}{ WOR } & less than 20 hours per week & -0.4326 & $* * *$ & -0.4315 & $* * *$ & -0.4356 & $* * *$ \\
\hline & from 21 to 40 hours per week & -0.1699 & $* * *$ & -0.1686 & $* * *$ & -0.1654 & $* * *$ \\
\hline & more than 40 hours per week & 0.0578 & $* * *$ & 0.0572 & $* * *$ & 0.0593 & $* * *$ \\
\hline \multirow{3}{*}{ SEC } & agriculture & 2.1015 & $* * *$ & 2.1746 & $* * *$ & 2.1101 & $* * *$ \\
\hline & industry & 2.1644 & $* * *$ & 2.2401 & $* * *$ & 2.1772 & $* * *$ \\
\hline & service & 2.0764 & $* * *$ & 2.1502 & $* * *$ & 2.0868 & $* * *$ \\
\hline \multirow{8}{*}{ OCU } & managerial & 0.5542 & $* * *$ & 0.5541 & $* * *$ & 0.5567 & $* * *$ \\
\hline & professional & 0.4457 & $* * *$ & 0.4392 & $* * *$ & 0.4402 & $* * *$ \\
\hline & technical & 0.3619 & $* * *$ & 0.3597 & $* * *$ & 0.3588 & $* * *$ \\
\hline & clerical & 0.2980 & $* * *$ & 0.2977 & $* * *$ & 0.2943 & $* * *$ \\
\hline & sales \& services & 0.2013 & $* * *$ & 0.2015 & $* * *$ & 0.1993 & $* * *$ \\
\hline & farmers. fishermen etc. & 0.5670 & $* * *$ & 0.5798 & $* * *$ & 0.6030 & $* * *$ \\
\hline & skilled workers & 0.1587 & $* * *$ & 0.1566 & $* * *$ & 0.1581 & $* * *$ \\
\hline & unskilled workers & 0.0426 & & 0.0468 & & 0.0398 & \\
\hline \multirow{8}{*}{ NUM } & persons in the household & 0.0347 & $* * *$ & & & & \\
\hline & children $\leq 5$ years old & & & & & 0.0079 & \\
\hline & children 6-15 years old & & & & & -0.0003 & \\
\hline & children 16-18 years old & & & & & -0.0890 & $* * *$ \\
\hline & persons $19-65$ years old & & & & & & \\
\hline & elderly persons $>65$ years old & -0.0657 & $* * *$ & -0.0298 & $* *$ & -0.0296 & $* *$ \\
\hline & unemployed children & -0.0544 & $* * *$ & -0.0180 & $* * *$ & & \\
\hline & employed persons & & & & & 0.0177 & \\
\hline \multicolumn{2}{|c|}{$\mathrm{R}^{2}$ adjusted } & \multicolumn{2}{|c|}{0.979} & \multicolumn{2}{|c|}{0.979} & \multicolumn{2}{|c|}{0.979} \\
\hline
\end{tabular}

Source: own elaboration. 
Table 9. Parame $\leq$ ter estimates of models estimated for women aged 55-65

\begin{tabular}{|c|c|c|c|c|c|c|c|}
\hline \multirow{3}{*}{$\begin{array}{c}\text { Feature } \\
1 \\
\end{array}$} & Model & \multicolumn{2}{|c|}{ MWC1 } & \multicolumn{2}{|c|}{ MWC2 } & \multicolumn{2}{|c|}{ MWC3 } \\
\hline & Variable & \multicolumn{6}{|c|}{ Parameter estimates } \\
\hline & 2 & \multicolumn{2}{|l|}{3} & \multicolumn{2}{|l|}{4} & \multicolumn{2}{|l|}{5} \\
\hline \multirow{2}{*}{ AGE } & age & 0.2412 & $* * *$ & 0.2397 & $* * *$ & 0.2437 & $* * *$ \\
\hline & $a g e^{2}$ & -0.0021 & $* * *$ & -0.0021 & $* * *$ & -0.0022 & $* * *$ \\
\hline REL & household head & 0.0935 & & 0.1067 & $*$ & 0.0943 & \\
\hline MAR & married & 0.1179 & $*$ & 0.1166 & $*$ & 0.1299 & $* *$ \\
\hline \multirow{5}{*}{ RES } & $>100$ thousand & -0.0418 & & -0.0349 & & -0.0379 & \\
\hline & 50-100 thousand & 0.0104 & & 0.0092 & & 0.0168 & \\
\hline & 10-50 thousand & -0.0137 & & -0.0190 & & -0.0138 & \\
\hline & 5-10 thousand & -0.0358 & & -0.0384 & & -0.0221 & \\
\hline & 2-5 thousand & 0.0959 & & 0.1227 & & 0.1027 & \\
\hline \multirow{5}{*}{ EDU } & university (at least ph.d.) & 0.6897 & $* *$ & 0.6950 & $* *$ & 0.6799 & $* *$ \\
\hline & university & 0.6028 & $* * *$ & 0.6105 & $* * *$ & 0.6170 & $* * *$ \\
\hline & post-secondary & 0.1519 & & 0.1440 & & 0.1606 & \\
\hline & vocational or general secondary & 0.1949 & $* *$ & 0.2124 & $* *$ & 0.2045 & $* *$ \\
\hline & primary or lower vocational & -0.0099 & & -0.0089 & & -0.0082 & \\
\hline \multirow{5}{*}{ SIZ } & $\leq 10$ employees & -0.2698 & $* * *$ & -0.2953 & $* * *$ & -0.2754 & $* * *$ \\
\hline & 11-19 employees & -0.1540 & $*$ & -0.1700 & * & -0.1588 & $*$ \\
\hline & 50-100 employees & -0.0100 & & -0.0423 & & -0.0034 & \\
\hline & 101-250 employees & 0.0465 & & 0.0409 & & 0.0519 & \\
\hline & $>250$ employees & 0.1339 & & 0.1081 & & 0.1355 & \\
\hline OWN & public & 0.0030 & & -0.0031 & & -0.0029 & \\
\hline \multirow{3}{*}{ WOR } & less than 20 hours per week & -0.8589 & $* * *$ & -0.8568 & $* * *$ & -0.8620 & $* * *$ \\
\hline & from 21 to 40 hours per week & -0.1700 & $* *$ & -0.1643 & $* *$ & -0.1762 & $* *$ \\
\hline & more than 40 hours per week & 0.2052 & & 0.2270 & & 0.1952 & \\
\hline \multirow{3}{*}{ SEC } & agriculture & -0.1596 & & -0.1901 & & -0.1756 & \\
\hline & industry & 0.2248 & & 0.2121 & & 0.2060 & \\
\hline & service & 0.1321 & & 0.1052 & & 0.1175 & \\
\hline \multirow{8}{*}{ OCU } & managerial & 0.5033 & $* * *$ & 0.4991 & ** & 0.4834 & $* *$ \\
\hline & professional & 0.1904 & & 0.2111 & & 0.1800 & \\
\hline & technical & 0.2763 & $*$ & 0.2820 & * & 0.2630 & * \\
\hline & clerical & 0.0449 & & 0.0583 & & 0.0367 & \\
\hline & sales \& services & 0.0085 & & 0.0361 & & 0.0042 & \\
\hline & farmers. fishermen etc. & 0.8395 & * & 0.8631 & * & 0.8594 & $*$ \\
\hline & skilled workers & 0.0303 & & 0.0150 & & 0.0236 & \\
\hline & unskilled workers & -0.1015 & & -0.0968 & & -0.1068 & \\
\hline \multirow{6}{*}{ NUM } & persons in the household & -0.0215 & & & & 0.0039 & \\
\hline & children $\leq 5$ years old & & & -0.0251 & & 0.0178 & \\
\hline & children 6-15 years old & & & -0.1029 & $*$ & & \\
\hline & children 16-18 years old & & & 0.1241 & & & \\
\hline & persons $19-65$ years old & & & & & -0.0414 & \\
\hline & elderly persons $>65$ years old & & & 0.0160 & & & \\
\hline \multicolumn{2}{|l|}{$\mathrm{R}^{2}$ adjusted } & \multicolumn{2}{|c|}{0.975} & \multicolumn{2}{|c|}{0.975} & \multicolumn{2}{|c|}{0.975} \\
\hline
\end{tabular}




\begin{tabular}{|c|c|c|c|c|c|c|c|}
\hline 1 & 2 & \multicolumn{2}{|l|}{3} & \multicolumn{2}{|l|}{4} & \multicolumn{2}{|l|}{5} \\
\hline \multirow{2}{*}{ AGE } & age & 0.2419 & $* * *$ & 0.2403 & $* * *$ & 0.2405 & $* * *$ \\
\hline & $a g e^{2}$ & -0.0022 & $* * *$ & -0.0021 & $* * *$ & -0.0021 & $* * *$ \\
\hline REL & household head & 0.0961 & * & 0.0966 & & 0.1092 & $*$ \\
\hline MAR & married & 0.1190 & $*$ & 0.1062 & $*$ & 0.1169 & $*$ \\
\hline \multirow{5}{*}{ RES } & $>100$ thousand & -0.0383 & & -0.0352 & & -0.0339 & \\
\hline & 50-100 thousand & 0.0150 & & 0.0199 & & 0.0103 & \\
\hline & 10-50 thousand & -0.0104 & & -0.0068 & & -0.0183 & \\
\hline & 5-10 thousand & -0.0293 & & -0.0255 & & -0.0320 & \\
\hline & 2-5 thousand & 0.1087 & & 0.1124 & & 0.1180 & \\
\hline \multirow{5}{*}{ EDU } & university (at least Ph.D.) & 0.6786 & $* *$ & 0.6818 & $* *$ & 0.6947 & $* *$ \\
\hline & university & 0.6105 & $* * *$ & 0.6092 & $* * *$ & 0.6101 & $* * *$ \\
\hline & post-secondary & 0.1605 & & 0.1626 & & 0.1427 & \\
\hline & vocational or general secondary & 0.2012 & $* *$ & 0.1996 & $* *$ & 0.2149 & $* *$ \\
\hline & primary or lower vocational & -0.0050 & & -0.0091 & & -0.0084 & \\
\hline \multirow{5}{*}{ SIZ } & $\leq 10$ employees & -0.2702 & $* * *$ & -0.2684 & $* * *$ & -0.2919 & $* * *$ \\
\hline & 11-19 employees & -0.1571 & * & -0.1556 & $*$ & -0.1704 & $*$ \\
\hline & 50-100 employees & -0.0061 & & -0.0084 & & -0.0422 & \\
\hline & 101-250 employees & 0.0529 & & 0.0571 & & 0.0401 & \\
\hline & $>250$ employees & 0.1385 & & 0.1410 & & 0.1104 & \\
\hline OWN & public & 0.0026 & & -0.0004 & & -0.0039 & \\
\hline \multirow{3}{*}{ WOR } & less than 20 hours per week & -0.8610 & $* * *$ & -0.8619 & $* * *$ & -0.8556 & $* * *$ \\
\hline & from 21 to 40 hours per week & -0.1739 & $* *$ & -0.1776 & $* *$ & -0.1617 & $* *$ \\
\hline & more than 40 hours per week & 0.1970 & & 0.1932 & & 0.2247 & \\
\hline \multirow{3}{*}{ SEC } & agriculture & -0.1552 & & -0.1492 & & -0.2153 & \\
\hline & industry & 0.2159 & & 0.2255 & & 0.1950 & \\
\hline & service & 0.1217 & & 0.1327 & & 0.0874 & \\
\hline \multirow{8}{*}{ OCU } & managerial & 0.4808 & $* *$ & 0.4782 & $* *$ & 0.5014 & $* *$ \\
\hline & professional & 0.1855 & & 0.1905 & & 0.2131 & \\
\hline & technical & 0.2630 & $*$ & 0.2612 & $*$ & 0.2847 & $*$ \\
\hline & clerical & 0.0423 & & 0.0432 & & 0.0610 & \\
\hline & sales \& services & 0.0107 & & 0.0146 & & 0.0351 & \\
\hline & farmers. fishermen etc. & 0.8282 & * & 0.8150 & & 0.8705 & $*$ \\
\hline & skilled workers & 0.0285 & & 0.0220 & & 0.0206 & \\
\hline & unskilled workers & -0.1042 & & -0.1100 & & -0.0895 & \\
\hline \multirow{8}{*}{ NUM } & persons in the household & -0.0194 & & & & & \\
\hline & children $\leq 5$ years old & & & & & -0.0177 & \\
\hline & children 6-15 years old & & & & & -0.0989 & $*$ \\
\hline & children 16-18 years old & & & & & 0.1216 & \\
\hline & persons 19-65 years old & & & & & & \\
\hline & elderly persons $>65$ years old & 0.0324 & & 0.0194 & & 0.0160 & \\
\hline & unemployed children & -0.0109 & * & -0.0346 & & & \\
\hline & employed persons & & & & & -0.0511 & \\
\hline \multicolumn{2}{|c|}{$\mathrm{R}^{2}$ adjusted } & \multicolumn{2}{|l|}{0.975} & \multicolumn{2}{|l|}{0.975} & \multicolumn{2}{|l|}{0.975} \\
\hline
\end{tabular}

Source: own elaboration. 
women and the five models (MWA1-MWA5) describing the monthly remuneration of the youngest female employees. Number of children 16-18 years old in models MWA6, MWB2 and MWB6, and number of employed persons in the household in model MWA6 are significant for the negative impact to salaries. In the models estimated on the basis of the subsample of women aged 25-54 years, variables representing: number of persons aged 19-65 (MWB3), children 5 years old and under (MWB3) and number of persons in the household have a significantly positive impact on monthly remuneration. While parameters standing for the number of elderly persons (MWB2, MWB3-MWB6), children not in employment (MWB4 and MWB5) and children 16-18 years old (MWB2 and MWB6) are significantly negative.

\section{Conclusion}

In our research we attempted to find out if the structure of the household influences the remuneration of Polish employees, what allows making a conclusion about the 'care penalty'. Analysis based on econometric models made it possible to formulate the following findings (Table 10).

Table 10. Models with a significant impact of "family variables"

\begin{tabular}{|c|c|c|c|}
\hline & Variables & Positive impact & Negative impact \\
\hline & sehold head & $\begin{array}{l}\text { MT1-6, MM1-6, MW1-6, } \\
\text { MWA1-2, MWA4-5, MWB1-6 }\end{array}$ & \\
\hline & ried & MM1-6, MWA4, MWC3 & MW1-6, MWB4 \\
\hline & $\begin{array}{l}\text { persons in the } \\
\text { household }\end{array}$ & MT1, MT4, MW1, MW4, MWB4 & MT3, MM3, MW3, MWB3 \\
\hline & children $<5$ & MT3, MT6, MWB3 & \\
\hline & children 6-15 & & \\
\hline $\begin{array}{l}\text { पे } \\
\dot{0} \\
\text { है }\end{array}$ & $\begin{array}{l}\begin{array}{l}\text { children 16-18 years } \\
\text { old }\end{array} \\
\end{array}$ & & $\begin{array}{l}\text { MT2, MT6, MM2, MM6, MW2, } \\
\text { MW6, MWA6, MWB2, MWB6 }\end{array}$ \\
\hline $\bar{z}$ & persons 19-65 & MT3, MM3, MWB3 & \\
\hline & elderly persons & & MWB2, MWB4-6 \\
\hline & $\begin{array}{l}\text { children not } \\
\text { in employment }\end{array}$ & & MT4, MW4, MWB4-5 \\
\hline & employed persons & & MM6, MWA6 \\
\hline
\end{tabular}

Source: own elaboration.

1. The existence of the 'motherhood penalty' is proved by models MT4, MW4, MWB4 and MWB5 since the variable representing the number of children not in employment is statistically significant and causes a decrease of monthly remuneration. It is worth mentioning that this variable is not significant in any model 
(containing this variable) estimated for the subsample of men. One can also note that the 'motherhood penalty' affects mostly women aged 25-54.

2. The 'care for the elderly penalty' is not so notable, but it is proved for women aged 25-54 since all the models containing the variable describing the number of persons aged 66 and more, show the significantly negative impact of this variable on the monthly remuneration.

3. Decreasing monthly remuneration is caused by the increase of number of children 16-18 years old visible in all the models containing this variable estimated for all the samples, subsamples of male and female employees, women aged 25-54 and 15-24 ( model MWA6).

4. The number of children aged 5 and below has a significant and positive impact on remuneration in models MT3, MT6 and MWB3.

5. The number of employed persons in a household (models MT3, MM3, and MWB3) and a number of family members (MT1, MT4, MW1, MW4, MWB4) significantly influence the increase of remuneration received by respondents. However, in the models containing the $\mathrm{S} 3$ set of variables this relation is the opposite (MT3, MM3, MW3, MWB3). Also, the number of employed persons in the household has a significant and negative impact in models MM6 and MWA6.

6. Households' heads receive higher remuneration that other members of families regardless of gender since the parameter standing for this variable is significantly positive in the majority of models, although the differences in salaries may be not significant in the group of the youngest female employees and the ones aged 55-65.

7. Married men earn more than unmarried ones (see models MM1-MM6), whereas married women earn less than unmarried female employees (models MW1MW6 and MWB4). However, the models estimated for the sample of married women aged 15-24 and 55-65 (MWA4 and MWC3) show the same tendency as the models estimated for male employees.

\section{Bibliography}

Blanchard O., 1997, Macroeconomics, Prentice Hall, Upper Saddle River.

Blau F.D., Kahn L.M., 2006, The U.S. gender pay gap in the 1990s: slowing convergence, Industrial and Labor Relations Review, vol. 60(1), pp. 45-66.

Cain G.G., 1986, The Economic Analysis of Labor Market Discrimination: A Survey, [in:] Ashenfeler O., Layard R., (ed.), Handbook of Labour Economics, Vol. I, Elsevier Science Publishers BV, pp. 693-785.

Cukrowska E., 2011, Investigating the Motherhood Penalty in a Post-Communist Economy: Evidence from Poland, CEU eTD Collection, Budapest.

Cukrowska-Torzewska E., 2015, She cares and he earns? The family gap in Poland, Ekonomia, vol. 42, pp. 43-47.

Cukrowska-Torzewska E., Lovasz A., 2016, Are children driving the gender wage gap? Comparative evidence from Poland and Hungary, The Economics of Transition, vol. 24(2), pp. 259-297. 
Fortin N.M., 2005, Gender role attitudes and the labour-market outcomes of women across OECD countries, Oxford Review of Economic Policy, vol. 21(3), pp. 416-438.

Grajek M., 2001, Gender pay gap in Poland, Discussion Paper no. FS IV 01-13, Wissenschaftszen-trum Berlin.

Juhn C., Murphy K., Pierce B., 1991, Accounting for the Slowdown in Black - White Wage Convergence, [in:] Kosters M. (ed.), Workers and Their Wages, AEI Press, Washington D.C., pp. 107-143.

Kompa K., Witkowska D., 2018, Factors affecting men's and women's earnings in Poland, Economic Research, vol.31(1), pp. 252-269.

Kot S.M. (ed.), 1999, Analiza ekonometryczna ksztaltowania się płac w Polsce w okresie transformacji, PWN, Warszawa, Kraków.

McConnell C.R., Brue S.L., 1986, Contemporary Labor Economics, McGraw Hill Book Co., New York.

Newell A., Reilly B., 2001, The gender wage gap in the transition from communism: some empirical evidence, Economic Systems, vol. 25, pp. 287-304.

Newell A., Socha M.W., 2005, The Distribution of Wages in Poland, 1992-2002, IZA Discussion Paper no. 1485, Institute for the Study of Labor, Bonn.

Newell A., Socha M.W., 2007, The Polish Wage Inequality Explosion, IZA Discussion Paper no. 2644, Institute for the Study of Labor, Bonn.

Neuman S., Oaxaca R.L., 2003, Estimating Labor Market Discrimination with Selectivity-Corrected Wage Equations: Methodological Considerations and An Illustration from Israel, Discussion Paper no. 2-2003, The Pinhas Sapir Center for Development Tel-Aviv University, Tel-Aviv.

Ñopo H., Daza N., Ramos J., 2011, Gender Earnings Gaps in the World, IZA Discussion Paper Series, Discussion Paper no. 5736, Institute for the Study of Labor, Bonn.

Podliński P., 2012, Analiza ekonometryczna płac kobiet i mężczyzn w Polsce w I kwartale 2009 r., praca magisterska napisana pod kierunkiem D. Witkowskiej, SGGW, Warszawa.

Witkowska D., 2012, Wage disparities in Poland. Econometric models of wages, Quantitative Methods in Economics, vol. 15(1), pp. 192-208.

Witkowska D., 2013, Gender disparities in the labor market in the EU, International Advances in Economic Research, vol. 19(4), pp. 331-354.

Witkowska D., 2014, Determinants of wages in Poland, Quantitative Methods in Economics, vol. 13(2), pp. 115-124.

\section{CZY STRUKTURA GOSPODARSTW DOMOWYCH WPLYWA NA WYNAGRODZENIA W POLSCE?}

Streszczenie: Podstawowymi determinantami płac są: ogólna sytuacja gospodarcza, indywidualne cechy pracowników oraz charakterystyki miejsca pracy. Na aktywność zawodową i wynagrodzenia wpływają także obowiązki rodzinne, szczególnie opiekuńcze. Celem pracy jest sprawdzenie, czy struktura gospodarstw domowych w Polsce wpływa na miesięczne wynagrodzenia pracowników. Badanie polega na estymacji modeli ekonometrycznych opisujących miesięczne wynagrodzenia na podstawie mikrodanych. Analizy przeprowadzono z wykorzystaniem próby wszystkich pracowników, oddzielnie z podziałem na pracowników obu płci oraz dla zatrudnionych kobiet z wyróżnionych trzech grup wiekowych. Badania wykazały, że: (1) mężczyźni zarabiają istotnie więcej niż kobiety, (2) zamężne kobiety zarabiają istotnie mniej niż niezamężne, a wśród mężczyzn relacja jest przeciwna, (3) obowiązki opiekuńcze wypełniają głównie kobiety, co w grupie wiekowej 25-55 lat istotnie wpływa na ich wynagrodzenia.

Słowa kluczowe: nierówności płacowe implikowane płcią, wynagrodzenia, struktura gospodarstw domowych. 